\title{
THE COLOMBIA-CANADA FREE TRADE AREA: A PARTIAL EQUILIBRIUM SIMULATION*
}

\author{
Catherine Pereira Villa** \\ Daniel Gómez Abella*** \\ Luis Omar Herrera***
}

Recibido: agosto 24 de 2011 • Aceptado: mayo 14 de 2012

\begin{abstract}
This paper uses disaggregated trade data for 2010 and applies ex-ante partial equilibrium modeling to calculate the impact of the preferential trade agreement between Canada and Colombia. The simulations carried out show aggregate trade creation could be one and a half times larger than trade diversion; trade between the two countries in the first year of the agreement could grow by approximately ten percent and will be focussed on a small number of goods; trade diversion is stronger with the largest trading partner of each signatory, namely the United States; and trade diversion is not strong in the case of Colombia's neighbors with which there was significant trade prior to the agreement.
\end{abstract}

\section{KEYWORDS}

Preferential trade agreement, trade creation, welfare effects, partial equilibrium simulation

\section{JEL CLASSIFICATION}

F15

\section{CONTENT}

Introduction; 1. Data and methodology; 2. Results; 3. Conclusions; Bibliography

\footnotetext{
This is a research article derived from the research project "The Colombia-Canada Free Trade Agreement: a Partial Equilibrium Simulation" by the research group in Logistics and International Business from Universidad de La Sabana. The project began in October 2010, ended in July 2011 and has had the support of Universidad de La Sabana and the Virtual Institute of the United Nations Conference on Trade and Development- UNCTADVi.

* M.A. in Economics and International Relations, University of Aberdeen, Aberdeen, United Kingdom; M.Sc. in Economics as part of the Scottish Doctoral Programme and M.Phil. in International Finance, University of Glasgow, Glasgow, United Kingdom; Assistant Professor, International School of Economics and Administrative Sciences, Universidad de La Sabana, Colombia: catherine.pereira@unisabana.edu.co.

*** B.A. and M.A. in Economics, Universidad de Los Andes, Bogotá, Colombia; Lecturer, International School of Economics and Administrative Sciences, Universidad de La Sabana, Colombia: daniel.gomez4@ unisabana.edu.co.

$* * *$ B.A. in Economics, Universidad de los Andes; Lecturer, International School of Economics and Administrative Sciences, Universidad de La Sabana, Colombia: lui-herr@uniandes.edu.co.
} 


\section{EL ÁREA DE LIBRE COMERCIO COLOMBO-CANADIENSE: UNA SIMULACIÓN DE EQUILIBRIO PARCIAL}

\section{RESUMEN}

Este documento utiliza datos desagregados sobre comercio para 2010 y aplica modelos de equilibrio parcial para calcular el impacto del acuerdo de comercio preferencial entre Canadá y Colombia. Las simulaciones realizadas muestran que la creación de comercio a partir del acuerdo podría ser una veces y media más grande que la desviación del comercio; el comercio entre los dos países en el primer año podría crecer aproximadamente un diez por ciento y se concentrará en un pequeño número de mercancías; la desviación del comercio es más fuerte con el mayor socio comercial de cada país signatario, a saber, los Estados Unidos; y la desviación del comercio no es fuerte en el caso de los vecinos de Colombia con los que había un comercio significativo antes del acuerdo.

\section{PALABRAS CLAVE}

Acuerdo de tratado comercial, comercio exterior, efectos de bienestar, simulación equilibrio parcial.

\section{CLASIFICACIÓN JEL}

F15

\section{CONTENIDO}

Introducción; 1. Datos y metodología; 2. Resultados; 3. Conclusiones; Bibliografía

\section{A ÁREA DE LIVRE COMÉRCIO ENTRE A COLÔMBIA E O CANADÁ: UMA SIMULAÇÃO DO EQUILÍBRIOU PARCIAL \\ RESUMO}

Este documento utiliza dados desagregados do comercio de 2010 e aplica a modelagem ex-ante do equilíbrio parcial para calcular o impacto do acordo de comercio preferencial entre o Canada e a Colômbia. As simulações mostram que a criação do comercio agregado poderia ser uma e meia vezes maior do que a diversão do comercio; o comercio entre os dois países poderia crescer aproximadamente dez por cento durante o primeiro ano e concentrara-se num pequeno numero de bens; a diversão do comercio é mais forte com o maior parceiro comercial de cada assinante, principalmente os Estados Unidos; e a diversão do comercio não é forte no caso dos vizinhos da Colômbia com os que havia um comercio significativo previa assinatura do acordo comercial.

\section{PALAVRAS-CHAVE}

Acordo de comercio preferencial, criação de comercio, efeitos de bem-estar, simulação de equilíbrio parcial

\section{CLASSIFICAÇÃO JEL}

\section{F15}

\section{CONTEUDO}

Introdução; 1. Dados e metodologia; 2. Resultados; 3. Conclusões; Bibliografia 


\section{INTRODUCTION}

The large number of countries involved in multilateral trade negotiations within the context of the World Trade Organization (WTO, 2010) has slowed the process of reaching agreements and encouraged countries to negotiate bilateral trade agreements. The expectation in these countries is that agreements of this type will allow for quicker results from trade liberalization, based on the assumption that freer trade is better from the standpoint of economic theory.

In 2008, Canada and Colombia agreed to a preferential trade agreement (PTA) that establishes a free trade area between the two countries, which took effect in August 2011. In this context, it is relevant to evaluate the potential impact of the agreement for both countries, since little has been published on its possible effects.

The advantages and disadvantages of PTAs have been at the center of the debate regarding their trade diversion (TD) and trade creation (TC) effects. Therefore, this research is valuable to trade policy-makers and to the sectors associated with the products Canada and Colombia trade, since it could empirically indicate what products might be affected by TC and TD. Furthermore, the results could enrich analysis and scrutiny of the strategic trade decisions taken by both countries. Revenue and welfare effects also are important inasmuch as they show net social effects due to the impact of tariff reductions on government revenue and on consumers and producers at the market level.

Since Colombia has promoted market access measures through the negotiation of trade agreements -with Central America, the European Union, South Korea and agreements with Chile, Japan and Russia, among others- and Canada has promoted its foreign direct investment in Latin America, one of the questions that arises is whether the potential results of the agreement are in line with the trade policy objectives of each country. Accordingly, this study also considers the export promotion agenda of Colombia's Export Promotion Office (PROEXPORT) in Toronto.

The theory on trade creation and trade diversion originates with the work of Viner (1950), who demonstrated the increase in trade within the members of a customs union does not always improve welfare, as had been assumed up until then. If trade increases due to trade creation, it would be welfare improving; however, the contrary would be the case if the increase is associated with trade diversion.

When there are preferential tariffs, such as those contained in the ColombiaCanada PTA, this changes the relative prices of goods between the countries that supply them. In turn and given the same a level of consumption, it also changes the market shares of the sources of those goods. Trade creation occurs when the reduction of tariffs on products coming from a specific country lowers the price 
of those products on the domestic market. This has a positive revenue effect on consumers by allowing for larger quantities of imports at the same income level. For the market, trade diversion in this case would imply the same imported quantities, except the goods would be entering the market from different countries whose share or participation in the market changes. According to Viner, welfare depends on how much trade creation and diversion are generated by an agreement.

The impact of a PTA is considered positive and creates trade if it allows domestically-produced goods to be substituted by others that are produced more efficiently by the partner country. On the other hand, trade diversion is considered negative, because it is associated with the substitution of efficiently-produced imports from other countries by less efficiently-produced goods coming from a PTA member. Albeit, some researchers have argued it may be politically easier to sign a PTA that is trade diverting, since it does not challenge the interests of domestic industries (Krishna, 1998; Wonnacott and Lutz, 1989).

The concepts of trade creation and diversion are extremely important due to their implications for welfare calculations. This is particularly true in a world that has seen important rates of growth in merchandise trade (UNCTAD, 2009) and where a country's net exports can represent a substantial share of its gross domestic product. A reduction in tariffs for an extended period of time typically increases imports and reduces domestic production of the item in question. This, in turn, will raise the consumer surplus, reduce the producer surplus, reduce government revenue and result in a welfare effect (be it a gain or a loss).

In addition to trade diversion and creation, there also can be a price effect. This is not always the case, but tends to occur when the elasticity of the export supply of a specific item is finite. Accordingly, a decline in price leads to an increase in demand, which pushes up the world price of the item in question. In all, the trade impact would consist of both trade diversion and trade creation effects, which are associated with quantities. There also is the aforementioned price effect to consider, which adds to the import value.

A number of empirical studies have been done to measure both ex-post and ex-ante trade liberalization efforts using different techniques, including general equilibrium models (GEM), partial equilibrium models (PEM) and gravity equation models (GVEM). Authors such as Krueger (1999) have analyzed trade flows before and after agreements are reached; others, such as Brown, Deardorff and Stern (1992), have simulated PTA effects based on both ex-post and ex-ante GEM, which simulate economy-wide effects for NAFTA, the United States, Japan and the effects of tariff liberalization for the Uruguay Round of Trade Negotiations. Other studies on European integration include the work of Haaland and Norman (1992). 
Some authors, such as Hess and Von Cramon-Taubadel (2007), have done a meta-analysis to shed light on the considerable variation in the results obtained with the models applied. Others, such as Gohin and Moschini (2006) and Narayanan, Hertel and Horridge (2009), have constructed mixed models of general and partial equilibrium, which claim to have more robust results in terms of trade policy analysis.

In the case of Colombia, several GEM studies have been carried out by the Economic Research Unit at the Colombian National Department of Planning (Dirección de Estudios Económicos del Departamento Nacional de Planeación, 2005), which has applied a GEM to the PTA negotiated with the United States. Botero (2004) studied the potential impact on Colombia of the Free Trade Zone of the Americas (ALCA). More recently, spatial considerations were introduced by Haddad, Bonet, Hewings and Perobelli (2008) into a GEM of the Colombian economy to identify the asymmetric impact of trade liberalization in different regions of the country.

In addition, Cárdenas and García (2004) applied a GVEM to simulate the effects of the PTA between Colombia and the United States. In general, a number of researchers and government agencies have used the GEM technique for analysis and decision-making purposes, but published material on the subject is scant.

It has been difficult for researchers to arrive at firm conclusions with regard to the gains or losses produced by PTAs. Krugman $(1991,1994)$ suggests PTAs are generally positive when established between natural trading partners. Bhagwati (1994) believes they tend to reflect differences in bargaining power on the part of their members -including many small developing countries-and says PTAs will have a multilateral effect anyway, to the extent that multilateral trade negotiations move forward. However, different results are used to support the various hypotheses surrounding PTAs and, particularly, whether TC outweighs TD (Clausing, 2001).

To measure the potential trade, welfare and revenue effects of the PTA in question, this study uses ex-ante partial equilibrium models (PEM) to simulate tariff liberalization for all goods imported between Colombia and Canada. PEM are used instead of GEM, since trade between Colombia and Canada is relatively minor and the objective of this paper is to capture the impact of liberalization in detail; future research will include ex-post analysis. Although any model is sensitive to the assumptions and parameters used (Frankel, 1997), the effects captured in this case through the use of a GEM may be difficult to ascertain as originating with liberalization measures themselves. For example, Krueger (1999) found NAFTA had less of an effect on Mexican trade flows during its first three years than on other aspects, such as exchange rate policies. In addition, Kehoe (2003) found the GEM used to predict the effects of NAFTA "drastically underestimated" its impact, mainly 
due to the increased trade in goods for which there was little or no trade prior to the agreement.

As for the results, the trade effect is the change in imports associated with trade creation and diversion. The welfare effect is associated with the change in consumer surplus, while the revenue effect is related to changes in government revenue.

This paper contains three sections. The first section describes the data and methodology used and characterizes bilateral trade between the countries, section two summarizes the results, and section three offers conclusions.

\section{DATA AND METHODOLOGY}

This paper uses WITS software to calculate the impact of the PTA. Developed by the World Bank and the United Nations Conference on Trade and Development (UNCTAD) $)^{1}$ it employs tariff data from the Trade Analysis and Information System (TRAINS) and the World Trade Organization's integrated database (IDB - WTO) and consolidated tariff schedule (CTS-WTO) $)^{2}$. TRAINS has an advantage in that it uses harmonized schedule nomenclature and includes data from 1988. Moreover, it can be complemented with the IDB-WTO database mentioned earlier with regard to import tariffs. The CTS-WTO database contains binding tariffs, which are useful when commenting on the negotiated tariff schedules.

This study uses PEM (applied ex-ante) to carry out simulations based on the agreed tariff schedules. The idea is to measure the specific effects that could occur at the sub-heading or six-digit level of the Harmonized Tariff Schedule. Although the trading volumes are small, Canadian-Colombian trade nearly tripled between 2002 and 2010, even without a PTA. The fact that there now is an agreement suggests both countries have identified opportunities for increased trade.

Using a GEM to examine economy-wide effects would be desirable. However, in the case of this agreement, we believe the scope of that method is limited and would not yield clear results, given the historically low share of Colombia-Canada trade ${ }^{3}$. The aggregation bias, which is common in GEM modeling, could be particularly strong and the welfare gains might be understated, given the limited size of total trade.

1 The authors acknowledge the use of WITS/TRAINS software, which was made available by the UNCTAD Virtual Institute in 2009.

2 They also wish to thank Manuela Tortora, Chief of the UNCTAD Technical Cooperation Service, the UNCTAD Virtual Institute and its Director, Ms. Vlasta Macku, and Mr. Hiroaki Kuwahara, Trade Information Section Chief with the Trade Analysis Branch at UNCTAD, for granting them access to the software and teaching them how to use it, as well as Nadia Rocha from the Economic Research and Statistics Division of the World Trade Organization, for her valuable comments

3 According to UN Comtrade data, trade between Colombia and Canada ranged from US\$ 466 million in 2002 to US\$1,306 million in 2010. 
In using a PEM, this study will consider each market in turn. This has several advantages in that a PEM has limited data requirements, is more appropriate when analyzing specific countries, the results are specified for individual goods as opposed to a particular type of goods, it solves the aggregation bias, and the calculations are transparent (i.e. parameters to which the models are sensitive do not have to be included to the extent of compromising the results).

PEMs also have limitations. For instance they may be sensitive to the elasticity parameters used and ignore interactions with other markets, although interactions can be modeled in PEMs. By definition, they use some economic variables, but not all. In this study, we use three different elasticity scenarios to compensate for these shortcomings and to gauge the effect on the simulations.

This paper will simulate the welfare and revenue effects resulting from the PTA and will identify possible effects on the set of goods that are traded at present. In doing so, it will also detect growth opportunities for those goods.

The welfare effect is related to the consumer surplus. However, since government revenue tends to decline with the reduction in tariffs and to rise when imports increase, the net welfare effects will be calculated based on what the economy gains as a whole.

This research uses disaggregated data from the World Bank COMTRADE database, which contains detailed information as of 1962 on imports, exports, values and quantities traded by the reporting country and by the partner, defined according to different trade classifications. The figures used in the simulations are for the year 2010 and are based on the harmonized system at the six-digit level. It is important to note that the forthcoming calculations and analysis are based on the trade data available for Canada and Colombia, and that no additional assumptions are made regarding possible changes in the economic and political conditions in either country.

Using the trade value and volumes for 2010 and the tariff reduction schedules for both agricultural and non-agricultural goods defined for Canada and Colombia within the PTA, this study estimates the amount of trade that could be created and diverted at the six-digit level. The negotiated liberalization schedules will be applied to the data to measure trade creation and diversion effects, based on the tariff rates currently in effect. In such cases, when products are protected by non-tariff measures, the ad-valorem equivalents are used in the simulations.

The model applied in this study is based on Laird and Yates (1986) (see Attachment 1). It assumes consumers optimize welfare by combining different sources of a specific product and, as such, spend on a product that originates in different countries. Accordingly, the change in prices has an impact on total spending through 
import demand elasticity; different elasticities are used, but they are the same for all varieties of the product.

To prevent imports from fluctuating in the calculations from one supplier to a PTA beneficiary, the model assumes that, even if goods are similar, they are imperfect substitutes. This is also known as the Armington assumption of consumer behavior. The elasticities of substitution used in the study reflect the fact that consumers choose between different sources when purchasing a product or item, depending on relative prices. As for export supply in response to changes in export prices, the model assumes the context is one of price takers; in other words, export supply elasticity is infinite or exogenous. This study will use United Nations information on elasticities; it can be run on WITS software, which the UN has improved in recent years. ${ }^{4}$

Based on the results of this process, the study calculates the changes in government revenue associated with the change in tariff and the change in welfare. Changes in consumer and producer surplus will be analyzed as well. However, with respect to welfare calculations, we know possible distortions that affect one market, such as specific tax policies, economies of scale and capital market issues, may influence the welfare effects identified for another market [17]. Therefore, with this in mind, the study will assess the markets where those characteristics might be found. Finally, the results of these simulations will be compared to the export promotion agenda of the Colombian Export Promotion Office (PROEXPORT) in Toronto.

Trade between Canada and Colombia increased 2.8 times between 2002 and 2010, having gone from US\$ 466 million in 2002 to US\$ 1,306 million in 2010. This amounts to $13.8 \%$ annual growth. Imports between Canada and Colombia rose at similar pace during the same period, but with extremely low average shares as a proportion of their respective total imports. Canadian purchases from Colombia increased at an annual rate of $13.7 \%$ with an average share of $0.1 \%$, while Colombian purchases from Canada grew at a rate of $14.7 \%$, with an average share of $2.1 \%$.

The trade intensity index for both countries was less than one during each of the last eight years. This means the value of trade between them is less than expected, given their share of world trade. The annual increase in this index for Canada with respect to Colombia was only $0.1 \%$, while the index for Colombia with Canada has declined by just under 3\% on an annual basis.

The complementarity index was calculated to determine the degree of association between the export specialty of one economy and the import specialty of the other. An index of 100 means one country imports exactly what the other exports.

$4 \quad$ WITS was developed initially by researchers from the Development Data Group at the World Bank and UNCTAD. It was coordinated by Olivier Jammes. 
Generally speaking, a high complementarity index signals a better outlook for welfare or profit through a trade agreement. Canada has more trade complementarity with Colombia than Colombia has with Canada. While Canada's complementarity index with Colombia rose at an annual rate of $1.1 \%$, Colombia's complementarity index with Canada declined at an annual rate of $1.4 \%$ (Table 1). In general, Canada exports a greater variety of goods to Colombia; in 2002 Canada sold 471 headings to Colombia and in 2010 it sold 1,246. In the same period, Colombia sold 327 and 424 headings to Canada.

Furthermore, in 2010 Canada exported 131 new items to Colombia; these included nuclear reactors, boilers, machinery and mechanical appliances, as well as electrical machinery and equipment parts thereof. The exports of new products accounted for 2.1 per cent of the total exports in that year. In the same year, Colombia sold 73 new items to Canada, among them nuclear assessment, boilers, machinery $\&$ mechanical appliance, tools, implements, cutlery, spoons and forks. These products accounted for $1.5 \%$ of the total exports that year. These statistics show that there is a recent tendency in favor of the diversification of exports between Canada and Colombia.

Table 1: Bilateral Trade between Canada and Colombia (2003-2010)*

\begin{tabular}{|l|l|l|c|c|c|c|c|c|c|c|c|c|}
\hline Reporter & Partner & Indicator & 2003 & 2004 & 2005 & 2006 & 2007 & 2008 & 2009 & 2010 & $\begin{array}{c}\text { Average } \\
\text { Growth } \\
\text { (\%) }\end{array}$ \\
\hline Canada & Colombia & $\begin{array}{l}\text { Total } \\
\text { Trade }\end{array}$ & 484.5 & 611.4 & 838.6 & 994.5 & $1,037.1$ & $1,250.1$ & $1,159.6$ & $1,306.3$ & 905.3 & 13.8 \\
\hline Canada & Colombia & $\begin{array}{l}\text { Share of } \\
\text { trade (\%) }\end{array}$ & 0.1 & 0.1 & 0.1 & 0.1 & 0.1 & 0.1 & 0.2 & 0.2 & 0.1 & 6.7 \\
\hline Canada & Colombia & Imports & 267.2 & 322.0 & 481.7 & 564.8 & 437.8 & 601.5 & 645.0 & 696.8 & 474.1 & 13.7 \\
\hline Canada & Colombia & $\begin{array}{l}\text { share of } \\
\text { imports }\end{array}$ & 0.1 & 0.1 & 0.2 & 0.2 & 0.1 & 0.1 & 0.2 & 0.2 & 0.1 & 5.9 \\
\hline Canada & Colombia & $\begin{array}{l}\text { Trade } \\
\text { intensity } \\
\text { index }\end{array}$ & 0.5 & 0.6 & 0.6 & 0.6 & 0.7 & 0.6 & 0.7 & 0.5 & 0.6 & 0.1 \\
\hline Canada & Colombia & $\begin{array}{l}\text { Comple- } \\
\text { mentarity } \\
\text { index }\end{array}$ & 54.9 & 55.7 & 56.3 & 59.2 & 60.5 & 57.5 & 60.4 & 61.1 & 58.0 & 1.1 \\
\hline Canada & Colombia & $\begin{array}{l}\text { Traded } \\
\text { sub- } \\
\text { headings }\end{array}$ & 622 & 759 & 964 & 1,149 & 1,163 & 1,253 & 1,154 & 1,246 & 975.7 & 12.9 \\
\hline Colombia & Canada & $\begin{array}{l}\text { Share of } \\
\text { trade (\%) }\end{array}$ & 1.8 & 1.6 & 1.6 & 1.5 & 1.5 & 1.5 & 1.6 & 1.7 & 1.6 & -0.7 \\
\hline Colombia & Canada & Imports & 313.4 & 384.3 & 389.1 & 500.2 & 648.6 & 794.8 & 674.7 & 823.1 & 533.6 & 14.7 \\
\hline Colombia & Canada & $\begin{array}{l}\text { share of } \\
\text { imports }\end{array}$ & 2.3 & 2.3 & 1.8 & 1.9 & 2.0 & 2.0 & 2.1 & 2.0 & 2.1 & -0.7 \\
\hline
\end{tabular}


Catherine Pereira Villa - Daniel Gómez Abella - Luis Omar Herrera

\begin{tabular}{|c|c|c|c|c|c|c|c|c|c|c|c|c|}
\hline Reporter & Partner & Indicator & 2003 & 2004 & 2005 & 2006 & 2007 & 2008 & 2009 & 2010 & Average & $\begin{array}{c}\text { Growth } \\
(\%)\end{array}$ \\
\hline Colombia & Canada & $\begin{array}{l}\text { Trade } \\
\text { intensity } \\
\text { index }\end{array}$ & 0.4 & 0.3 & 0.5 & 0.4 & 0.3 & 0.4 & 0.5 & 0.3 & 0.4 & -2.9 \\
\hline Colombia & Canada & $\begin{array}{l}\text { Comple- } \\
\text { mentarity } \\
\text { index }\end{array}$ & 36.3 & 39.4 & 40.9 & 42.7 & 43.9 & 42.7 & 41.1 & 34.5 & 40.0 & -1.4 \\
\hline Colombia & Canada & $\begin{array}{l}\text { Traded } \\
\text { sub- } \\
\text { headings }\end{array}$ & 354 & 426 & 497 & 459 & 456 & 419 & 405 & 473 & 424 & 4.7 \\
\hline
\end{tabular}

*: In US millions

Source: COMTRADE database and authors' calculations

As to the make-up of trade flows, the main bilateral imports between Canada and Colombia during 2010 are presented according to the chapters in the Harmonized Tariff Schedule (HS).

Table 2 shows the main Canadian imports from Colombia. More than 64\% are concentrated in two chapters: Mineral Fuels, Oils \& Products of their Distillation (40.9\%) and Coffee, Tea, Matï and Spices (23.5\%). As part of Canada's purchases, both these chapters account for a larger share than Canadian purchases from the rest of the world, primarily in the case of coffee, tea, matï and spices.

Table 2: Main Canadian Imports from Colombia in 2010

\begin{tabular}{|c|l|c|c|c|}
\hline HS-2 & \multicolumn{1}{|c|}{ Description } & $\begin{array}{c}\text { Imports from } \\
\text { Colombia* }\end{array}$ & $\begin{array}{c}\text { Colombia's share } \\
\text { (\%) }\end{array}$ & World share (\%) \\
\hline 27 & Mineral fuels, oils \& products of their distillation & 284.7 & 40.9 & 39.1 \\
\hline 9 & Coffee, tea, mati and spices & 163.8 & 23.5 & 1.3 \\
\hline 8 & Edible fruit and nuts; citrus peel & 80.2 & 11.5 & 3.6 \\
\hline 6 & Live trees \& other plant; bulbs, roots & 68.3 & 9.8 & 0.4 \\
\hline 17 & Sugar and sugar confectionary & 16.1 & 2.3 & 1.1 \\
\hline 39 & Plastics and articles thereof & 10.9 & 1.6 & 13.1 \\
\hline 21 & Miscellaneous edible preparations & 9.3 & 1.3 & 1.9 \\
\hline 38 & Miscellaneous chemical products & 6.8 & 1 & 4 \\
\hline 69 & Ceramic products & 4.3 & 0.6 & 1 \\
\hline 62 & Articles of apparel \& clothing accessories & 4.1 & 0.6 & 3.7 \\
\hline & All other chapters & 48.2 & 6.9 & 30.9 \\
\hline & Total & 696.8 & 100 & 100 \\
\hline
\end{tabular}

*: In US millions

Source: COMTRADE database and authors' calculations*: In US millions 
The ten chapters with the most tariffs charged to Colombia in Canada during 2010 are shown in Table 3. However, this list does not include the two chapters responsible for $64 \%$ of the imports 5 . The weighted average rate charged to all the chapters, as a whole, was $3.1 \%$.

Table 3: Canadian Tariffs on Colombian Imports in 2010

\begin{tabular}{|c|c|c|c|}
\hline \multirow{2}{*}{ HS-2 } & \multirow{2}{*}{ Description } & \multicolumn{2}{|c|}{ Average } \\
\hline & & Weighted (\%) & Simple(\%) \\
\hline 64 & Footwear, gaiters and the like; parts of such articles & 17,9 & 13,6 \\
\hline 63 & Other made up textile articles; sets; worn clothing & 16,7 & 15,4 \\
\hline 62 & Articles of apparel $\&$ clothing accessories, not knitted/crocheted & 16,5 & 16,8 \\
\hline 61 & Articles of apparel \& clothing accessories, knitted or crocheted & 15,6 & 17,2 \\
\hline 57 & Carpets and other textile floor coverings & 14 & 14 \\
\hline 89 & Ships, boats and floating structures & 9,5 & 9,5 \\
\hline 6 & Live trees $\mathcal{E}$ other plants; bulbs, roots; cut flowers & 8,1 & 5,6 \\
\hline 24 & Tobacco and manufactured tobacco substitutes & 8 & 7,8 \\
\hline 65 & Headgear and parts thereof & 7,6 & 5,7 \\
\hline \multirow[t]{2}{*}{69} & Ceramic products & 7,3 & 5,8 \\
\hline & All the chapters & 3,1 & 3,5 \\
\hline
\end{tabular}

Source: TRAINS data base

The main Colombian imports from Canada in 2010 are shown in Table 4. Cereals (22.1\%) and nuclear reactors, boilers, machinery and mechanical appliances account for the largest portions (22.1\% and $13.7 \%$ respectively). The share of cereals imported from Canada is far greater than the share of cereals Colombia imports from the rest of the world.

Table 4: Main Colombian Imports from Canada in 2010

\begin{tabular}{|c|c|c|c|c|}
\hline HS-2 & Description & $\begin{array}{l}\text { Imports from } \\
\text { Canada* }\end{array}$ & $\begin{array}{c}\text { Canada's share } \\
(\%)\end{array}$ & World share (\%) \\
\hline 10 & Cereals & 181.9 & 22.1 & 3.2 \\
\hline 84 & $\begin{array}{l}\text { Nuclear reactors, boilers, machinery } \& \text { mechanical } \\
\text { appliances }\end{array}$ & 112.7 & 13.7 & 15 \\
\hline 88 & Aircraft, spacecraft, and parts thereof & 75.4 & 9.2 & 4.7 \\
\hline
\end{tabular}

These chapters are namely mineral fuels, oils and products of their distillation and coffee, tea, mati and spices. 
Catherine Pereira Villa - Daniel Gómez Abella - Luis Omar Herrera

\begin{tabular}{|c|l|c|c|c|}
\hline HS-2 & \multicolumn{1}{|c|}{ Description } & $\begin{array}{c}\text { Imports from } \\
\text { Canada* }\end{array}$ & $\begin{array}{c}\text { Canada's share } \\
\text { (\%) }\end{array}$ & World share (\%) \\
\hline 48 & Paper \& paperboard; art of paper & 71.7 & 8.7 & $1, .6$ \\
31 & Fertilisers & 64.3 & 7.8 & 1.5 \\
7 & Edible vegetables and certain roots & 61.1 & 7.4 & 0.4 \\
87 & Vehicles o/t railway/tramway roll-stock & 26.9 & 3.3 & 10.1 \\
85 & Electrical machinery, equipment parts thereof & 25.2 & 3.1 & 10 \\
30 & Pharmaceutical products & 22.5 & 2.7 & 3.6 \\
39 & Plastics and articles thereof & 21.5 & 2.6 & 4.2 \\
& All other chapters & 159.9 & 19.4 & 45.7 \\
\hline & Total & 823.1 & 100 & 100 \\
\hline
\end{tabular}

*: In US millions

Source: COMTRADE and TRAINS database.

The ten chapters with the most tariffs charged to Canada in Colombia during 2010 are shown in Table 5. As for the chapters with the most imports, the only one on this list is that pertaining to vehicles o/t railway/tramway roll-stock and access, which accounted for just $0.3 \%$ of the imports from Canada. The weighted average rate charged to all the chapters, as a whole, was $14 \%$.

Table 5: Colombian Tariffs on Canadian Imports in 2010

\begin{tabular}{|c|l|c|c|}
\hline \multirow{2}{*}{ HS-2 } & \multicolumn{1}{|c|}{ Description } & \multicolumn{2}{|c|}{ Average } \\
\cline { 3 - 4 } & & Weighted & Simple \\
\hline 4 & Dairy products; bird eggs; natural honey; edible products & 92.3 & 69.3 \\
61 & Vehicles o/t railway/tramway roll-stock & 21.2 & 16 \\
62 & Articles of apparel \& clothing accessories, not knitted/crocheted & 20 & 20 \\
22 & Articles of apparel \& clothing accessories, knitted or crocheted & 20 & 20 \\
57 & Beverages, spirits and vinegar & 20 & 20 \\
3 & Carpets and other textile floor coverings & 20 & 20 \\
60 & Kish E crustaceans, mollusks \& other aquatic invertebrates & 20 & 20 \\
46 & Manufactures of straw, esparto/other plaiting material & 20 & 20 \\
\cline { 2 - 4 } 2 & Meat and edible meat offal & 20 & 20 \\
\hline \multirow{2}{*}{5} & All the chapters & 20 & 20 \\
\hline
\end{tabular}

Source: TRAINS database 
The scenarios that were simulated to quantify the impact of the free trade agreement on the Colombian and Canadian economies pertained to tariff relief in Colombia on all products imported from Canada during 2010 and tariff relief in Canada on all products imported from Colombia during 2010.

Therefore, these are extreme scenarios intended to distinguish the general tendencies of the repercussions of economic liberalization within the scope of the agreement. The elasticity of import demand, the elasticity of export supply and the elasticity of substitution are the parameters for both scenarios that reflect the behavior of consumers and export partners in order to calibrate the simulations.

The elasticity of supply is considered infinite, inasmuch as the export partners perform as price takers and changes in demand are met with adjustments in quantities. The values determined by the system for the six-digit level of the Harmonized Tariff Schedule are used for the elasticity of import demand, which identifies the sensitivity of demand to changes in the price of imports. The value considered for the elasticity of substitution, which determines the degree of substitution between different variety of goods, according to the export partner, is 1.5 for each product or item.

\section{RESULTS}

The results of the simulated scenarios pertain to the effect on trade, welfare and revenue in Canada and Colombia. The trade effect is the impact on the flow of imports. The welfare effect is the variation in the consumer surplus, given the increased quantities of goods consumed, and the revenue effect is the reduction in revenue collected from import tariffs. The trade effect is the combined result of trade creation and trade diversion. Trade creation stems from the direct increase in imports resulting from the reduction in tariffs on imports from the beneficiary country. In the case of Canada, it is 1.4 times larger than the trade diversion effect.

The products for which the trade, welfare and revenue effects are greatest in the case of both Canada and Colombia are shown in Attachment 2 at the sub-heading (HS-6) level of the Harmonized Tariff Schedule.

The impact of Tariff relief in Canada on imports from Colombia would generate an increase in imports equivalent to 15.6 million dollars, given the creation of 9.2 million dollars in trade and 6.5 million dollars in trade diversion. Ecuador and the United States are the countries that would suffer the sharpest decline in sales to Canada; their imports would fall by 1.8 and 1.7 million respectively (Table 6). 
Catherine Pereira Villa - Daniel Gómez Abella - Luis Omar Herrera

Table 6: Trade Effect According to Canada's Trading Partners

\begin{tabular}{|l|c|c|c|}
\hline \multicolumn{1}{|c|}{ Trading Partner } & $\begin{array}{c}\text { Trade Creation } \\
\text { (US\$ Millions) }\end{array}$ & $\begin{array}{c}\text { Trade Deviation } \\
\text { (US\$ Millions) }\end{array}$ & $\begin{array}{c}\text { Trade Effect } \\
\text { (US\$ Millions) }\end{array}$ \\
\hline Colombia & 9.2 & 6.5 & 15.6 \\
\hline Japan & 0.0 & 0.0 & 0.0 \\
\hline Africa & 0.0 & -0.1 & -0.1 \\
\hline Rest of the world & 0.0 & -0.1 & -0.1 \\
\hline India & 0.0 & -0.1 & -0.1 \\
\hline Rest of Europe & 0.0 & -0.1 & -0.1 \\
\hline Rest of South America & 0.0 & -0.1 & -0.1 \\
\hline Mexico & 0.0 & -0.1 & -0.1 \\
\hline Central America & 0.0 & -0.2 & -0.2 \\
\hline European Union & 0.0 & -0.5 & -0.5 \\
\hline Rest of Asia & 0.0 & -0.5 & -0.5 \\
\hline China & 0.0 & -1.0 & -1.0 \\
\hline United States & 0.0 & -1.7 & -1.7 \\
\hline Ecuador & 0.0 & -1.8 & -1.8 \\
\hline Total & 9.2 & 0.0 & 9.2 \\
\hline
\end{tabular}

Source: WITS-SMART. Authors' calculations.

There would be no significant change in the percentage of total Canadian imports. The welfare of Canadian consumers would improve by US\$ 0.5 million, and US\$ 8.4 million in tariffs would cease to be collected. The results of the three effects for the sub-headings in which the trade effect is the greatest are shown in Table 7 .

Table 7: The Trade, Welfare and Revenue Effect for Canada

\begin{tabular}{|l|l|c|c|c|c|}
\hline HS-6 & \multicolumn{1}{|c|}{ Description } & $\begin{array}{c}\text { Trade Effect } \\
\text { (US\$ Millions) }\end{array}$ & $\begin{array}{c}\text { Change in } \\
\text { Imports } \\
(\%)\end{array}$ & $\begin{array}{c}\text { Welfare Effect } \\
\text { (US\$ Millions) }\end{array}$ & $\begin{array}{c}\text { Revenue Effect } \\
\text { (US\$ Millions) }\end{array}$ \\
\hline 060311 & (2007-) (- Fresh:)-Roses & 2.4 & 6.0 & 0.2 & -2.2 \\
\hline 060319 & $(2007-)(-$ Fresh:)-Other & 1.6 & 3.6 & 0.0 & -1.3 \\
\hline 060312 & $(2007-)(-$ Fresh:)--Carnations & 1.3 & 9.3 & 0.1 & -1.1 \\
\hline 060314 & (2007-) (- Fresh:)-Chrysanthemums & 0.7 & 8.6 & 0.0 & -0.6 \\
\hline 271019 & (2002-) Other & 0.4 & 0.0 & 0.0 & -0.1 \\
\hline
\end{tabular}


The Colombia-Canada free trade area: a partial equilibrium simulation

\begin{tabular}{|l|l|c|c|c|c|}
\hline HS-6 & \multicolumn{1}{|c|}{ Description } & $\begin{array}{c}\text { Trade Effect } \\
\text { (US\$ Millions) }\end{array}$ & $\begin{array}{c}\text { Change in } \\
\text { Imports } \\
(\%)\end{array}$ & $\begin{array}{c}\text { Welfare Effect } \\
\text { (US\$ Millions) }\end{array}$ & $\begin{array}{c}\text { Revenue Effect } \\
\text { ( US\$ Millions) }\end{array}$ \\
\hline 330690 & Other & 0.2 & 0.3 & 0.0 & -0.2 \\
\hline 681381 & $\begin{array}{l}(2007-) \text { (- Not containing asbestos:)-- } \\
\text { Brake linings and pads }\end{array}$ & 0.1 & 0.5 & 0.0 & -0.2 \\
\hline 380892 & (2007-) (- Other:)-- Fungicides & 0.1 & 0.1 & 0.0 & -0.2 \\
\hline 620342 & Of cotton & 0.1 & 0.0 & 0.0 & -0.1 \\
\hline 691010 & Of porcelain or china & 0.1 & 0.1 & 0.0 & -0.1 \\
\hline & All other sub-headings & 2.1 & 0.0 & 0.2 & -2.2 \\
\hline & Total & 9.2 & 0.0 & 0.5 & -8.4 \\
\hline
\end{tabular}

Source: WITS-SMART. Authors' calculations.

Most of the imports with the best results in terms of their effect on trade also have the most welfare and revenue effect. They are concentrated under Heading 0603, which includes cut flowers and flower buds of a kind suitable for bouquets or for ornamental purposes, fresh, dried, dyed, bleached, impregnated or otherwise prepared; they account for $65.8 \%$ of the trade effect, $64.5 \%$ of the welfare effect and $63.2 \%$ of the revenue effect.

The impact of tariff relief in Colombia on imports from Canada would generate an increase in imports equivalent to US\$184.1 million resulting from US\$14.1 million in trade creation and US\$ 70 million in trade diversion. The country to suffer the largest setback in sales would be the United States, given US\$35.7 million in goods and services Colombia would cease to import (Table 8).

Table 8: Trade Effect per Colombia's Trading Partners

\begin{tabular}{|l|c|c|c|}
\hline \multicolumn{1}{|c|}{ Trading Partner } & $\begin{array}{c}\text { Trade Creation } \\
\text { (US\$ Millions) }\end{array}$ & $\begin{array}{c}\text { Trade Deviation } \\
\text { (US\$ Millions) }\end{array}$ & $\begin{array}{c}\text { Trade Effect } \\
\text { (US\$ Millions) }\end{array}$ \\
\hline Canada & 114.1 & 70.0 & 184.1 \\
\hline Africa & 0.0 & 0.0 & 0.0 \\
\hline India & 0.0 & -0.3 & -0.3 \\
\hline Ecuador & 0.0 & -0.3 & -0.3 \\
\hline Central America & 0.0 & -0.4 & -0.4 \\
\hline Venezuela & 0.0 & -0.4 & -0.4 \\
\hline Rest of the world & 0.0 & -1.0 & -1.0 \\
\hline Rest of South America & 0.0 & -1.4 & -1.4 \\
\hline
\end{tabular}


Catherine Pereira Villa - Daniel Gómez Abella - Luis Omar Herrera

\begin{tabular}{|l|c|c|c|}
\hline \multicolumn{1}{|c|}{ Trading Partner } & $\begin{array}{c}\text { Trade Creation } \\
\text { (US\$ Millions) }\end{array}$ & $\begin{array}{c}\text { Trade Deviation } \\
\text { (US\$ Millions) }\end{array}$ & $\begin{array}{c}\text { Trade Effect } \\
\text { (US\$ Millions) }\end{array}$ \\
\hline Rest of Europe & 0.0 & -1.5 & -1.5 \\
\hline Japan & 0.0 & -1.6 & -1.6 \\
\hline Brazil & 0.0 & -1.7 & -1.7 \\
\hline Korea, Rep. & 0.0 & -1.8 & -1.8 \\
\hline Mexico & 0.0 & -1.9 & -1.9 \\
\hline Chile & 0.0 & -2.1 & -2.1 \\
\hline Rest of Asia & 0.0 & -2.2 & -2.2 \\
\hline China & 0.0 & -2.4 & -2.4 \\
\hline Argentina & 0.0 & -7.2 & -7.2 \\
\hline European Union & 0.0 & -8.0 & -8.0 \\
\hline United States & 0.0 & -35.7 & -35.7 \\
\hline Total & 114.1 & 0.0 & 114.1 \\
\hline
\end{tabular}

Source: WITS-SMART. Authors' calculations.

Colombia's total imports would increase by $0.3 \%$. The welfare of Canadian consumers would improve by US\$11.5 million and US\$ 78.1 million in tariffs would cease to be collected. The results of the three effects for the sub-headings in which the trade effect is the greatest are shown in Table 9.

Table 9: Trade, Welfare and Revenue Effect by Product

\begin{tabular}{|l|l|c|c|c|c|}
\hline HS-6 & \multicolumn{1}{|c|}{ Description } & $\begin{array}{c}\text { Trade Effect } \\
\text { (US\$ Millions) }\end{array}$ & $\begin{array}{c}\text { Change in Imports } \\
(\%)\end{array}$ & $\begin{array}{c}\text { Welfare Effect } \\
\text { (US\$ Millions) }\end{array}$ & $\begin{array}{c}\text { Revenue Effect } \\
\text { (US\$ Millions) }\end{array}$ \\
\hline 100190 & Other & 41.2 & 12.1 & 3.0 & -15.2 \\
\hline 870410 & $\begin{array}{l}\text { Dumpers designed for off- } \\
\text { highway use }\end{array}$ & 12.1 & 4.9 & 1.6 & -6.8 \\
\hline 271019 & (2002-) Other & 6.0 & 0.5 & 0.5 & -2.4 \\
\hline 870324 & $\begin{array}{l}\text { Of a cylinder capacity excee- } \\
\text { ding 3,000 cc }\end{array}$ & 5.6 & 5.3 & 1.5 & -8.9 \\
\hline 841940 & Distilling or rectifying plant & 5.2 & 106.5 & 0.4 & -0.2 \\
\hline 120400 & $\begin{array}{l}\text { Linseed, whether or not } \\
\text { broken. }\end{array}$ & 3.4 & 400.6 & 0.2 & -0.1 \\
\hline 100300 & Barley. & 2.2 & 3.4 & 0.1 & -3.2 \\
\hline 841480 & Other & 1.9 & 1.7 & 0.2 & -2.0 \\
\hline 071340 & Lentils & 1,8 & 5.7 & 0.1 & -3.0 \\
\hline
\end{tabular}


The Colombia-Canada free trade area: a partial equilibrium simulation

\begin{tabular}{|l|l|c|c|c|c|}
\hline HS-6 & \multicolumn{1}{|c|}{ Description } & $\begin{array}{c}\text { Trade Effect } \\
\text { (US\$ Millions) }\end{array}$ & $\begin{array}{c}\text { Change in Imports } \\
\text { (\%) }\end{array}$ & $\begin{array}{c}\text { Welfare Effect } \\
\text { (US\$ Millions) }\end{array}$ & $\begin{array}{c}\text { Revenue Effect } \\
\text { (US\$ Millions) }\end{array}$ \\
\hline 040490 & Other & 1.7 & 1573.1 & 0.8 & -0.1 \\
\hline & The remaining sub-headings & 33.1 & 0.1 & 3.0 & -36.2 \\
\hline & Total & 114.1 & 0.3 & 11.4 & -78.1 \\
\hline
\end{tabular}

Source: WITS-SMART. Authors' calculations.

The three effects are concentrated largely under Heading 1001, which includes wheat and meslin (HS-4). It accounts for $36.1 \%$ of the trade effect, $26.5 \%$ of the welfare effect and $19.5 \%$ of the revenue effect.

The results of the model depend on its elasticity values. The value of the elasticity of substitution used in the model is 1.5; this is the value used by default in WITS. To verify the sensitivity of the results obtained with respect to changes in this elasticity, the scenarios were simulated again using different values. According to the results, the higher the elasticity of substitution, the greater the trade effect stemming from tariff relief in Canada on imports from Colombia; however, the tendencies remain the same. Ecuador and the United States are the countries that suffer the most diversion in trade (Table 10).

Table 10: Trade Effect Sensitivity to Tariff Relief in Canada

\begin{tabular}{|l|c|c|c|}
\hline \multirow{2}{*}{ Trading Partner } & \multicolumn{3}{c|}{ Elasticity of Substitution } \\
\cline { 2 - 4 } & 1.0 & 1.5 & 2.0 \\
\hline Colombia & 13.5 & 15.6 & 17.8 \\
\hline Japan & 0.0 & 0.0 & -0.1 \\
\hline Africa & 0.0 & -0.1 & -0.1 \\
\hline Rest of the world & 0.0 & -0.1 & -0.1 \\
\hline India & -0.1 & -0.1 & -0.1 \\
\hline Rest of Europe & -0.1 & -0.1 & -0.1 \\
\hline Rest of South America & -0.1 & -0.1 & -0.1 \\
\hline Mexico & -0.1 & -0.1 & -0.2 \\
\hline Central America & -0.1 & -0.2 & -0.3 \\
\hline European Union & -0.4 & -0.5 & -0.7 \\
\hline Rest of Asia & -0.4 & -0.5 & -0.7 \\
\hline China & -0.7 & -1.0 & -1.4 \\
\hline
\end{tabular}


Catherine Pereira Villa - Daniel Gómez Abella - Luis Omar Herrera

\begin{tabular}{|l|c|c|c|}
\hline \multirow{2}{*}{\multicolumn{1}{|c|}{ Trading Partner }} & \multicolumn{3}{|c|}{ Elasticity of Substitution } \\
\cline { 2 - 4 } & 1.0 & 1.5 & 2.0 \\
\hline United States & -1.2 & -1.7 & -2.3 \\
\hline Ecuador & -1.2 & -1.8 & -2.4 \\
\hline Total & 9.2 & 9.2 & 9.2 \\
\hline
\end{tabular}

Source: WITS-SMART. Authors' calculations.

The same occurs with the trade effect of tariff relief in Colombia. The United States continues to suffer the most trade diversion (Table 11).

Table 11: Trade Effect Sensitivity to Tariff Relief in Colombia

\begin{tabular}{|l|c|c|c|}
\hline \multirow{2}{*}{ Trading Partner } & \multicolumn{3}{|c|}{ Elasticity of Substitution } \\
\cline { 2 - 4 } & 1.0 & 1.5 & 2.0 \\
\hline Canada & 160.8 & 184.1 & 207.4 \\
\hline Africa & 0.0 & 0.0 & 0.0 \\
\hline India & -0.2 & -0.3 & -0.4 \\
\hline Ecuador & -0.2 & -0.3 & -0.4 \\
\hline Central America & -0.2 & -0.4 & -0.5 \\
\hline Venezuela & -0.2 & -0.4 & -0.5 \\
\hline Rest of the world & -0.6 & -1.0 & -1.3 \\
\hline Rest of South America & -0.9 & -1.4 & -1.8 \\
\hline Rest of Europe & -1.0 & -1.5 & -2.0 \\
\hline Japan & -1.1 & -1.6 & -2.2 \\
\hline Brazil & -1.1 & -1.7 & -2.3 \\
\hline Korea, Rep. & -1.2 & -1.8 & -2.4 \\
\hline Mexico & -1.3 & -1.9 & -2.5 \\
\hline Chile & -1.4 & -2.1 & -2.8 \\
\hline Rest of Asia & -1.5 & -2.2 & -3.0 \\
\hline China & -2.4 & -3.2 \\
\hline Argentina & -7.2 & -9.6 \\
\hline
\end{tabular}




\begin{tabular}{|l|c|c|c|}
\hline \multirow{2}{*}{\multicolumn{1}{|c|}{ Trading Partner }} & \multicolumn{3}{c|}{ Elasticity of Substitution } \\
\cline { 2 - 4 } & 1.0 & 1.5 & 2.0 \\
\hline European Union & -5.4 & -8.0 & -10.7 \\
\hline United States & -23.7 & -35.7 & -47.8 \\
\hline Total & 114.1 & 114.1 & 114.1 \\
\hline
\end{tabular}

Source: WITS-SMART. Authors' calculations.

\section{CONCLUSIONS}

The simulations conducted with disaggregated trade data for 2010 and the negotiated liberalization schedules applied ex-ante using PEM, show aggregate TC could be one and a half times greater than TD.

Trade between Canada and Colombia will increase by approximately ten percent during 2011, but this increase will be concentrated in a small number of goods; $70 \%$ of the effect on Canadian exports, as estimated, is associated with the sale of cereals (particularly wheat), dumpers or trucks designed for off-highway use, petroleum, motor vehicles above 3,000 cubic centimeters, and machinery, plant and laboratory equipment.

Seventy percent (70\%) of the effect on Colombian exports will be concentrated on cut flowers and flower buds (roses, carnations and chrysanthemums) and oil.

With regard to cereals, particularly wheat, TD basically will affect the United States and Argentina in term of their trade with Colombia. Colombia will have an advantage over Ecuador in cut flowers and flower buds in the Canadian market, and probably will buy fewer motor vehicles from the United States, particularly those used to transport goods. Thus, for both Canada and Colombia, TD is stronger with their largest trading partner, namely the United States. In the case of Canada, the magnitude of TD is very small as opposed to Colombia, where TD associated with the United States is greater. Furthermore, TD is not strong in the case of Colombia's neighbors with which there was significant trade prior to the PTA.

The export promotion agenda of the PROEXPORT office in Toronto targets Canada as one of the markets where it wants to expand Colombia's trade activities and this will occur. However, in the short term, the authors anticipate little diversification of exports to Canada apart from the commodities already being sold to that market.

There are limitations to this study. For example, it was conducted ex-ante and the effect on goods not currently traded is not accounted for, nor is the impact of 
the agreement on investment in specific sectors such as telecommunications and financial services, or the export of professional services, nor the participation of Colombian small and medium sized enterprises in Canada's public procurement. Moreover, a smaller number of products in the simulations may underestimate the ultimate effect of the PTA. It is also worth noting that the effects of the PTA between Colombia and the United States -which has come into effect on May 15th 2012- may reduce the TD effects estimated in this research.

Finally, future research should include ex-post analysis; address the effect of Canadian foreign direct investment (FDI) in Colombia and the benefits obtained through investment provisions for specific sectors, as they may have welfare effects for PTA members and non-members alike.

\section{BIBLIOGRAPHY}

Bhagwati, J. (1994). Regionalism and multilateralism: An overview. En: J. de Melo and A. Panagariya (Eds.), New dimensions in regional integration. Cambridge: Cambridge University Press, p. 22-51.

Botero, J. (2004). Impacto del ALCA y el TLC sobre el empleo en Colombia. Una evaluación mediante equilibrio general computable. RED COLOMBIA COMPITE

Contract No. 079. Ministry of Trade, Industry and Tourism and the Corporation for the Development of Research and the Teaching of Economics (Corporación para el Desarrollo de la Investigación y la Docencia Económica - CIDE), p. 5-9.

Brown, D.K., Deardorff A.V., and Stern R.M. (1992). A North American free trade agreement: Analytical issues and computational assessment. World Economy 15, p. 11-29.

Cárdenas, M., and García, C.. El modelo gravitacional y el TLC entre Colombia y Estados Unidos (2004) FEDESARROLLO Working Papers, No. 27, p. 2-8.

Clausing K.A. (2001). Trade creation and trade diversion in the Canada-United States Free Trade Agreement. The Canadian Journal of Economics, Vol 34, No. 3, p. 677-696.

Dirección de Estudios Económicos del Departamento Nacional de Planeación, (2005). Colombia y el TLC: Efectos sobre la Distribución del Ingreso y la Pobreza. Archivos de Economía, Documento 289, p. 25-31.

Frankel, J.A. (1997). Regional trading blocs in the World Economic System (Washington, DC: Institute for International Economics). p, 19-2.

Gohin A., and Moschini G. (2006). Evaluating the market and welfare impacts of agricultural policies in developed countries: Comparison of partial and general equilibrium measures. Review of Agricultural Economics, Vol. 28, p. 195-211. 
Haaland, J., and Norman V. (1992). Global production effects of European integration. In L.A. Winters (Ed.)," Trade Flows and Trade Policy after 1992. Cambridge: Cambridge University Press, p. 67-89.

Hadad, E., Bonet, J., Hewings, J., and Perobelli, F. (2008). Spatial aspects of trade liberalization in Colombia: A general equilibrium approach. Cuadernos de Economía, No. 515, p. 1-41.

Hess, S., and von Cramon-Taubadel, S. (2007). Assessing general and partial equilibrium simulations of Doha Round outcomes using meta-analysis. Center for Globalization CEGE. Discussion Paper 67, p. 1-35.

Kehoe, T., (2003). An evaluation of the performance of applied general equilibrium models of the impact of NAFTA. Federal Reserve Bank of Minneapolis: Research Department Staff Report 320, p. 1-56.

Krishna, P., (1998). Regionalism and multilateralism: A political economy approach. Quarterly Journal of Economics, Vol. 113, No. 1, p. 227-251.

Krueger, A. (1999). Trade creation and diversion under NAFTA. Working Paper 7429: National Bureau of Economic Research, p. 1-32.

Krugman, P. (1991). The move toward free trade zones. Policy implications of trade and currency zones: A symposium sponsored by the Federal Reserve Bank of Kansas City. Kansas City: Federal Reserve Bank of Kansas City, p. 7-42.

Krugman, P. (1994). Regionalism vs. multilateralism: Analytical notes. In J. de Melo and A. Panagariya (Eds.), New dimensions in regional integration. Cambridge: Cambridge University Press, p. 58-79.

Laird, S., and Yeats, A. (1986). The UNCTAD trade policy simulation model. United Nations Conference on Trade and Development.

Narayanan, B., Hertel, T., and Horridge, J.M. (2010). Disaggregated data and trade policy analysis: The value of linking partial and general equilibrium models. Economic Modelling, Vol. 27, p. 755-766.

United Nations Conference on Trade and development, (2009). Trade and Development Report 2009, p. 3, Table 1.2

Viner, J. (1950). The customs union issue. New York: Carnegie Endowment for International Peace.

Wonnacott, P., and Lutz, M. (1989). Is there a case for free trade agreements? In Schott,J. (Ed.), Free trade areas and US trade policy. Washington D.C.: Institute for International Economics, p. 59-84.

World Trade Organization, (2010). RTA Database available at: http://www.wto.org/english/ tratop _ e/region _ e/region _ e.htm; 474 The WTO has been notified of preferential trade agreements (PTA) as of July 2010. 


\section{APPENDIX 1}

The simulations were carried out with the WITS/SMART model based on Laird and Yates (1986). It uses a partial equilibrium framework and calculates trade creation and diversion effects, quantifies the revenue effects associated with tariff changes and the welfare effect measured as a result of lower import prices and their effect on consumer surplus.

The notation of the following formulas is:

P: Price

Y: Income

$\mathrm{X}$ : Exports

Ex: Elasticity of export supply with respect to export price

M: Imports

Mo: Imports from non-member countries

Em: Elasticity of import demand with respect to price on the domestic market

Es: Elasticity of substitution based on relative prices for the same product from different countries

V: Importing country output

R: Revenue

W: Welfare

$\Delta$ : Change

T: Tariff or non-tariff ad-valorem equivalence

C: Trade creation

D: Trade Diversion

i: A specific product or item

j: Importing country data

k: Exporting country data

A country's (j) imports (M) of a product or item (i) from country (k) are based on the level of income in $\mathrm{j}$, as well as the price of those imports and the price of the product or item in the exporting country. 
$\operatorname{Mijk}=F(Y j, P i j, P i k)$

The supply of the product or item on the part of the exporting country is a function of:

$$
\mathrm{X} i j k=\mathrm{F}(\mathrm{P} i k j)
$$

As a result,

$\mathrm{Mijk}=\mathrm{Xijk}$

We assume the price of a product or item in the importing market is equal to the price in the exporting market, plus shipping costs, insurance costs and an amount equal to the tariff or non-tariff ad-valorem equivalent. Therefore,

Pijk $=$ Pikj $(1+$ Tijk $)$

The revenue earned by the exporting country would be:

Rikj $=$ Xikj (Pikj)

The elasticity of import demand in relation to the domestic price can be written as:

$$
\begin{aligned}
\Delta \text { Mijk } / \text { Mijk } & =\operatorname{Em}(\Delta \text { Pijk } / \text { Pijk }) \\
\Delta \text { Mijk } / \text { Mijk } & =\operatorname{Em}(\Delta \text { Tijk } /(1+\text { Tijk })+\Delta \text { Pijk } / \text { Pijk })
\end{aligned}
$$

The elasticity of export supply with respect to the world price is:

$$
\begin{aligned}
& \Delta \text { Pijk/Pijk }=(\Delta \mathrm{Xikj} / \mathrm{Xikj}) / \mathrm{Ex} \\
& \Delta \mathrm{Mijk} / \mathrm{Mijk}=\Delta \mathrm{Xikj} / \mathrm{Xikj}
\end{aligned}
$$

Since the trade creation effect is the increase in the demand for goods coming from a partner country associated with the price reduction as a result of the change in tariff or tariff equivalent, the formula for trade creation can be written as:

$$
\text { Cijk }=\text { Mijk } . \text { Em. } \Delta \text { Tijk/(1+Tijk })(1(\mathrm{Em} / \mathrm{Ex}))
$$

If the Ex is infinite and therefore exogenous to the model, then the denominator in the previous equation is equal to 1.

$$
(1+\mathrm{Tijk})(1(\mathrm{Em} / \mathrm{Ex})) \equiv 1 \text {. }
$$

The trade diversion effect would be associated with the change in the country that supplies a product or item as a result of the change in the import price from one country, while others remain unchanged. This happens either because prices fall in one specific country or because a country that supplies the product or item benefits from a preferential measure, while others do not. 
This study will simulate different elasticities of substitution that we consider reasonable, although using the same value for the same type of goods, since this elasticity is a significant parameter of the model and the value it takes usually has a very strong impact on trade diversion. We will use the data on elasticities available through WITS, which employs a default value of 1.5, and will use market penetration data for estimation, if available.

$$
E s=\underline{\Delta\left(\sum \mathrm{Mijk} / \sum \mathrm{MijK}\right) /\left(\sum \mathrm{Mijk} / \sum \mathrm{MijK}\right)}
$$

Where k represents the imports from one supplier and $\mathrm{K}$ represents imports from the rest of the suppliers. The sum total of $\mathrm{k}$ and $\mathrm{K}$ does not apply for product groups (i), nor for imports (j).

The equation for trade diversion can be expressed as:

$$
\mathrm{Dijk}=\underline{\mathrm{M} i j k} \frac{\sum \mathrm{Mijk} . \mathrm{MijK} . \mathrm{Es} \cdot \frac{\Delta(\mathrm{P} i j k / \mathrm{P} i j \mathrm{~K})}{\mathrm{P} i j k / \mathrm{P} i \mathrm{~K}}}{\sum \mathrm{Mijk} \sum \mathrm{Mijk}+\sum \mathrm{MijK}+\sum \mathrm{Mijk} . \mathrm{Es} . \frac{\Delta(\mathrm{P} i j k / \mathrm{P} i j \mathrm{~K})}{\mathrm{Pijk} / \mathrm{PijK}}}
$$

The total trade effect will be obtained by adding trade creation and trade diversion in terms of single products and product groups.

As mentioned above, there can be a price effect as well, which also is known as the terms of trade effect. WITS software assumes the elasticity of supply is infinite and, as such, there are no price effects on exports. Therefore, revenue for the exporting country increases with the rise in exports. This study presumes that the numerous countries serving as sources for products is consistent with this assumption, except in the case of certain capital intensive commodities for which the elasticity of supply may not be infinite; in such instances, a change in the assumption may be warranted. In this case, the revenue effect would be based on the percentage increase in exports added to the percentage increase in prices.

$$
\begin{aligned}
& \Delta \operatorname{Pikj} / \operatorname{Pikj}=(\Delta \mathrm{Tijk} /(1+\text { Tijk })) .(E m /(E m-E x)) \\
& \Delta \operatorname{Rikj} / \operatorname{Rikj}=(\Delta \mathrm{Tijk} /(1+\text { Tijk })) . E m .((1+\text { Ex }) / E x-E m))
\end{aligned}
$$




\section{APPENDIX 2}

Trade Effect Estimated for Canada at the Six-digit Level

\begin{tabular}{|l|l|c|c|}
\hline HS-6 & \multicolumn{1}{|c|}{ Description } & $\begin{array}{c}\text { Trade Effect } \\
\text { (US\$ Millions) }\end{array}$ & $\begin{array}{c}\text { Share of Trade Effect } \\
\text { (\%) }\end{array}$ \\
\hline 060311 & (2007-) (- Fresh:)-- Roses & 2.4 & 26.1 \\
\hline 060319 & (2007-) (- Fresh:)-- Other & 1.6 & 17.3 \\
\hline 060312 & (2007-) (- Fresh:)-- Carnations & 1.3 & 14.2 \\
\hline 060314 & (2007-) (- Fresh:)-- Chrysanthemums & 0.7 & 7.7 \\
\hline 271019 & (2002-) Other & 0.4 & 4.6 \\
\hline 330690 & Other & 0.2 & 1.9 \\
\hline 681381 & (2007-) (- Not containing asbestos:)-- Brake linings and pads & 0.1 & 1.6 \\
\hline 380892 & (2007-) (- Other:)-- Fungicides & 0.1 & 1.4 \\
\hline 620342 & Of cotton & 0.1 & 1.4 \\
\hline 691010 & Of porcelain or china & 0.1 & 1.2 \\
\hline
\end{tabular}

Source: WITS-SMART. Authors' calculations.

Welfare Effects Estimated for Canada at the Six-digit Level

\begin{tabular}{|l|l|c|c|}
\hline HS-6 & \multicolumn{1}{|c|}{ Description } & $\begin{array}{c}\text { Welfare Effect } \\
\text { (US\$ Millions) }\end{array}$ & $\begin{array}{c}\text { Share of Welfare } \\
\text { Effect } \\
\text { (\%) }\end{array}$ \\
\hline 060311 & (2007-) (- Fresh:)-- Roses & 0.2 & 36.8 \\
\hline 060312 & (2007-) (- Fresh:)-- Carnations & 0.1 & 10.9 \\
\hline 060319 & (2007-) (- Fresh:)-- Other & 0.0 & 9.9 \\
\hline 060314 & (2007-) (- Fresh:)_Chrysanthemums & 0.0 & 6.2 \\
\hline 720430 & Waste and scrap of tinned iron or steel & 0.0 & 2.4 \\
\hline 720429 & Other & 0.0 & 1.5 \\
\hline 732310 & $\begin{array}{l}\text { Iron or steel wool; pot scourers and scouring or polishing pads, } \\
\text { gloves and the like }\end{array}$ & 0.0 & 1.5 \\
\hline
\end{tabular}




\begin{tabular}{|c|l|c|c|}
\hline HS-6 & \multicolumn{1}{|c|}{$\begin{array}{c}\text { Description } \\
\text { Welfare Effect } \\
\text { (US\$ Millions) }\end{array}$} & $\begin{array}{c}\text { Share of Welfare } \\
\text { Effect } \\
\text { (\%) }\end{array}$ \\
\hline 710900 & $\begin{array}{l}\text { Base metals or silver, clad with gold, not further worked than } \\
\text { semi-manufactured. }\end{array}$ & 0.0 & 1.5 \\
\hline 710420 & Other, unworked or simply sawn or roughly shaped & 0.0 & 1.3 \\
\hline 720310 & Ferrous products obtained by direct reduction of iron ore & 0.0 & 1.3 \\
\hline & All other sub-headings & 0.1 & 26.7 \\
\hline & Total & 0.5 & 100.0 \\
\hline
\end{tabular}

Source: WITS-SMART. Authors' calculations.

Revenue Effects Estimated for Canada at the Six-digit Level

\begin{tabular}{|l|l|c|c|}
\hline HS-6 & \multicolumn{1}{|c|}{ Description } & $\begin{array}{c}\text { Revenue Effect } \\
\text { (US\$ Millions) }\end{array}$ & $\begin{array}{c}\text { Share of Revenue } \\
\text { Effect } \\
\text { (\%) }\end{array}$ \\
\hline 060311 & (2007-) (- Fresh:)-- Roses & -2.2 & 26.4 \\
\hline 060319 & (2007-) (- Fresh:)-- Other & -1.3 & 16.0 \\
\hline 060312 & (-Fresh:) -Carnations & -1.1 & 13.1 \\
\hline 060314 & (- Fresh:)-- Chrysanthemums & -0.6 & 7.2 \\
\hline 380892 & (2007-) (- Other:)-- Fungicides & -0.2 & 2.4 \\
\hline 681381 & (2007-) (- Not containing asbestos:)-- Brake linings and pads & -0.2 & 2.0 \\
\hline 330690 & Other & -0.2 & 2.0 \\
\hline 620342 & Of cotton & -0.1 & 1.7 \\
\hline 691010 & Of porcelain or china & -0.1 & 1.6 \\
\hline & $\begin{array}{l}\text { Gelatin (including gelatin in rectangular (including square) } \\
\text { sheets, whether or not surface worked or coloured) and gelatin } \\
\text { derivatives; isinglass; other glues of animal origin, excluding } \\
\text { casein glues of heading 35.01. }\end{array}$ & -0.1 & 1.1 \\
\hline 350300 & -2.2 & 26.5 \\
\hline & All other sub-headings & -8.4 & 100.0 \\
\hline
\end{tabular}

Source: WITS-SMART. Authors' calculations. 
Trade effect estimated for Colombia at the six-digit level

\begin{tabular}{|l|l|c|c|}
\hline HS-6 & \multicolumn{1}{|c|}{ Description } & $\begin{array}{c}\text { Trade Effect } \\
\text { (US\$ Millions) }\end{array}$ & $\begin{array}{c}\text { Share of the Trade Effect } \\
\text { (\%) }\end{array}$ \\
\hline 100190 & Other & 41.2 & 36.1 \\
\hline 870410 & Dumpers designed for off-highway use & 12.1 & 10.6 \\
\hline 271019 & (2002-) Other & 6.0 & 5.3 \\
\hline 870324 & Of a cylinder capacity exceeding 3,000 cc & 5.6 & 4.9 \\
\hline 841940 & Distilling or rectifying plant & 5.2 & 4.5 \\
\hline 120400 & Linseed, whether or not broken. & 3.4 & 3.0 \\
\hline 100300 & Barley. & 2.2 & 1.9 \\
\hline 841480 & Other & 1.9 & 1.7 \\
\hline 071340 & Lentils & 1.8 & 1.6 \\
\hline 040490 & Other & 1.7 & 1.5 \\
\hline & All other sub-headings & 33.1 & 29.0 \\
\hline & Total & 114.1 & 100.0 \\
\hline
\end{tabular}

Source: WITS-SMART. Authors' calculations.

Welfare effects estimated for Colombia at the six-digit level

\begin{tabular}{|c|l|c|c|}
\hline \multirow{2}{*}{ HS-6 } & \multicolumn{1}{|c|}{ Description } & Welfare Effect & Share of Welfare Effect \\
\cline { 3 - 4 } & & (US\$ Millions) & (\%) \\
\hline 100190 & Other & 3.0 & 26.5 \\
\hline 870410 & Dumpers designed for off-highway use & 1.6 & 13.8 \\
\hline 870324 & Of a cylinder capacity exceeding 3,000 cc & 1.5 & 13.5 \\
\hline 040490 & Other & 0.8 & 7.0 \\
\hline 271019 & (2002-) Other & 0.5 & 4.2 \\
\hline 841940 & Distilling or rectifying plant & 0.4 & 3.6 \\
\hline 040410 & Whey and modified whey, whether or not concentrated & 0.2 & 2.0 \\
\hline 841480 & Other containing added sugar or other sweetening matter & 0.2 & 2.0 \\
\hline 120400 & Linseed, whether or not broken. & 0.2 & 1.5 \\
\hline 020329 & Other & 0.1 & 1.2 \\
\hline & All other sub-headings & 2.8 & 24.6 \\
\hline & Total & 11.4 & 100.0 \\
\hline
\end{tabular}

Source: WITS-SMART. Authors' calculations. 
Catherine Pereira Villa - Daniel Gómez Abella - Luis Omar Herrera

Revenue effects estimated for Colombia at the six-digit level

\begin{tabular}{|l|l|c|c|}
\hline HS-6 & \multicolumn{1}{|c|}{ Description } & $\begin{array}{c}\text { Revenue Effect } \\
\text { (US\$ Millions) }\end{array}$ & $\begin{array}{c}\text { Share of Revenue Effect } \\
\text { (\%) }\end{array}$ \\
\hline 100190 & Other & -15.2 & 19.4 \\
\hline 870324 & Of a cylinder capacity exceeding 3.000 cc & -8.9 & 11.4 \\
\hline 870410 & Dumpers designed for off-highway use & -6.8 & 8.7 \\
\hline 100300 & Barley & -3.2 & 4.1 \\
\hline 071340 & Lentils & -3.0 & 3.9 \\
\hline 271019 & (2002- ) Other & -2.4 & 3.0 \\
\hline 841480 & Other & -2.0 & 2.6 \\
\hline 310420 & Potassium chloride & -1.7 & 1.8 \\
\hline 841210 & Reaction engines other than turbojets & -1.4 & 1.7 \\
\hline 300490 & Other & -1.4 & 41.3 \\
\hline & All other sub-headings & -32.2 & 100.0 \\
\hline & Total & -78.1 & \\
\hline
\end{tabular}

Source: WITS-SMART. Authors' calculations. 